\title{
GRADUATED PHARMACISTS PROMOTING ORAL HEALTH IN FEDERATION OF BOSNIA AND HERZEGOVINA
}

\author{
Milka Dančević-Gojković ${ }^{1}$ E Elma Sokić-Begović ${ }^{2}$ \\ ${ }^{1}$ Public Health Institute of Federation Bosnia and Herzegovina \\ ${ }^{2}$ Federal Ministry of Health
}

Rad je primljen 17.10.2020.. Rad je recenziran 28.10.2020. Rad je prihvaćen 19.10.2020.

\begin{abstract}
:
Background: Community pharmacists are healthcare professionals that play a crucial role in delivering quality healthcare to people, including oral health-related problems and dental hygiene products, as part of health promotion.

In order to better understand these issues in $\mathrm{FB} \& \mathrm{H}$, this exploratory study aimed at assessing the knowledge, attitude and practice of Pharmacy interns in Federation of B\&H in regard to oral health and their educational needs, with the ultimate goal of enhancing their future role in promoting oral health and oral hygiene practices as pharmacists.

Methods: This cross-sectional study was carried out among pharmacy interns in 2019 by using self-administered, semi-structured questionnaire. The results were statistically analysed using descriptive statistics.

Results: The most frequently reported oral condition/products on which pharmacists provided advice during their practice were: (other) gum related problems like pain, redness, tenderness, inflammation etc.), Toothache and Denture related problems. Mouthwash, Toothbrush and Toothpaste were reported respectively. Regarding the knowledge of participants about prevention oriented oral health behaviours, $80.8 \%$ of participant strongly agree and agree to recommended oral health behaviors. Participants showed positive attitudes toward their role in oral health care and willingness to improve their knowledge about this issue.

Conclusion: This study shows that pharmacy interns in FB\&H have good knowledge about preventive oral health behaviours, average knowledge related to oral health care and have positive attitude to their important role in maintenance of oral health despite all barriers and difficulties. The pharmacist interns expressed their need for education/training to enhance their practice.
\end{abstract}

Key words: pharmacist, oral health, promotion, $\mathrm{FBiH}$

Correspondence:

Prim dr Milka Dančević-Gojković ${ }^{1}$

Zavod za javno zdravstvo Federacije Bosne i Hercegovine

Titova 9,

Sarajevo

Bosna i Hercegovina 


\section{INTRODUCTION}

Pharmacy is a dynamic profession and pharmacists have long served as medication experts due to their knowledge and accessibility, and are frequently approached by consumers with health-related questions. $(1,2)$ Community pharmacists are trustworthy, and well-respected healthcare professionals that could play a crucial role in delivering quality healthcare to people. $(3,4,5)$ Studies have reported that pharmacists are the second most used source for advice on general health matters and, therefore, can and should also be used in an oral health capacity $(2,6,7)$ Rather than consult a dentist or physician, many individuals with oral problems seek help from their pharmacists. (8) Previous findings revealed that pharmacists are asked at least one question every week about some oral health-related problem, with almost half of them about mouth ulcers. (4) In fact, with a large number of customers visiting, the pharmacists actually are exposed to more people with dental problems than an average dentist does. $(9,10,11)$

We have to understand that community pharmacies are a setting for the public who cannot attend dental care to consult for dental advices. $(8,10)$ Costs and accessibility are among the reasons that prevent general public from having proper dental care. $(11,12)$

There are a variety of ways by which the pharmacist can take a frontline approach to oral disease prevention trough encouraging effective oral hygiene practices; promoting healthy eating; smoking cessation, encouraging use of dental services and preventive therapies; and giving parents and other family caregivers information, motivation, confidence, and the skills to prevent oral disease $(8,13)$ Moreover, most of the products used to treat or maintain oral health can be purchased from pharmacies. Therefore, community pharmacists should be able to adequately counsel about the appropriate use of dental products available in the pharmacy such as products for dental decay/tartar build up (toothpaste/mouthwash), denture hygiene, gum care, etc. In addition, community pharmacists should be able to identify the signs and symptoms of the most frequently encountered oral health problems within the scope of their knowledge and practice, and know when to refer to a dentist/physician. (4) In fact, cost, fear from and difficult access to dentists (inconvenient location and time) are among the reasons that prevent general public from having proper dental care $(4,12,14)$

In addition, pharmacist role as adviser regarding side effects of prescribed or requested medicine in relation to oral health should not be disregarded. The role played by the pharmacist in the delivery of oral health care has been taken into consideration only recently. (2) According to the studies the recommendations of oral health products also depended mainly on the limited knowledge of the pharmacist about the product and their personal experience. $(2,8,12)$ Based on these reports, it is obvious that pharmacists play an important role in oral health promotion.

To the best of our knowledge, no studies were conducted in Federation Bosnia and Herzegovina to evaluate the knowledge, attitude, and practice toward Oral Health Among Pharmacist or pharmacy students or to explore their attitude toward role of community pharmacists in the provision of oral health care advice. In order to better understand these gaps, this exploratory study aimed at assessing the knowledge, attitude and practice of Pharmacy interns in Federation of B\&H regarding oral health and the educational needs of pharmacists, with the ultimate goal of enhancing their role in promoting oral health and hygiene. Our primary goal was to explore graduate pharmacist knowledge and attitude related to oral health and oral hygiene products, which is not based only on their personal experience, but on their formal education. The study was conducted on sample of pharmacy interns in FB\&H to obtain information relevant for further study about the issue.

\section{METHODS}

This cross-sectional study was carried out among pharmacy interns in 2019 by self-administered, semi-structured and paper-based questionnaire. The participants filled the questionnaire, voluntary 
and anonymous, during their formal internship classes. Data was collected by a single investigator, who personally met the pharmacy interns and explained to them the purpose of the study. The same investigator collected the completed questionnaires.

Since, there is no standardised questionnaire, for the purpose of this study, it was used questionnaire created by authors based on references from existing literature. Questionnaire was composed of 4 different sections: 1. Socio-demographic and practice characteristics: age, gender, location of the Faculty of Pharmacy, location of the pharmacy; 2. Question related to pharmacists' practices toward oral health and hygiene products (open- ended question), 3. Questions related to perceived knowledge in oral health (5 closed-ended questions an 3 (open- ended questions); 4. Questions related to pharmacists' attitude.

The results were statistically analysed using Office Excel 2013. Relating to the nature of data obtained by this study only descriptive statistics was used to assess its results. The mean percentage scores and frequency distribution were calculated.

\section{RESULTS}

A total of 62 pharmacy interns participated in this survey, 56 (90.3\%) female and 6 (9.7\%) male. The two thirds of the participants in the study were between 24 and 25 year old.

Respondents named three locations in FB\&H where their Faculty of Pharmacy is located. The most frequent location reported was Sarajevo (61.3\%).

Respondents named 20 different locations in FB\&H where they practice their internship. Sarajevo (40.3\%) was the most frequent location reported.

\section{Practices}

Practices of pharmacy interns regarding provided advices on oral health conditions and oral hygiene products was assessed trough an open-ended question. Because of variety of answers obtained, they were categorised into 15 categories.

The most frequently reported oral condition/ products on which pharmacists provided advice were: Other gum related problems (incl. pain, red- ness, tenderness, inflammation etc.) (21.3\%), Toothache (15.4\%) and Denture related problems (13.6\%). Mouthwash, Toothbrush and Toothpaste were reported in $10.0 \%, 9.0 \%, 7.2 \%$ respectively.

Table 1 . The most frequently reported oral condition/products on which pharmacy interns provided advice

\begin{tabular}{|l|l|l|l|}
\hline & & $\begin{array}{l}\text { o r a l } \\
\text { h e a l t h } \\
\text { a d v i c e } \\
\text { requests } \\
\text { N }\end{array}$ & \\
\hline 1 & Cather gum related problems & 47 & $21.3 \%$ \\
\hline 2 & Toothache & 34 & $15.4 \%$ \\
\hline 3 & Denture related problems & 30 & $13.6 \%$ \\
\hline 4 & Mouthwash & 22 & $10.0 \%$ \\
\hline 5 & Toothbrush & 20 & $9.0 \%$ \\
\hline 6 & Toothpaste & 16 & $7.2 \%$ \\
\hline 7 & Oral ulcer & 14 & $6.3 \%$ \\
\hline 8 & Other mouth related problems & 14 & $6.3 \%$ \\
\hline 9 & Bleeding gums & 6 & $2.7 \%$ \\
\hline 10 & Mouth malodour & 5 & $2.3 \%$ \\
\hline 11 & Interdental brushes & 4 & $1.8 \%$ \\
\hline 12 & Medicine request & 3 & $1.4 \%$ \\
\hline 13 & Tooth whitening & 3 & $1.4 \%$ \\
\hline 14 & Teething & 2 & $0.9 \%$ \\
\hline 15 & No experience & 1 & $0.5 \%$ \\
\hline & Grand Total & 221 & $100.0 \%$ \\
\hline & Chart 1. Oral health advice requests categories \\
\hline
\end{tabular}

\section{Knowledge}

Knowledge of pharmacy interns was assessed trough 8 questions, five of them were closed-ended with 5-point Likert scale and 3 of them were openended, so we had to categorise answers for further analysis.

Table 2. Closed-ended questions related to knowledge about oral health behaviour in the form of claims with most frequent answers

\begin{tabular}{|l|l|l|}
\hline NoQ & Questions in form of claims & $\begin{array}{l}\text { \% of respon- } \\
\text { dents who } \\
\text { answered } \\
\text { strongly } \\
\text { agree and } \\
\text { agree }\end{array}$ \\
\hline
\end{tabular}




\begin{tabular}{|l|l|l|}
\hline Q1 & $\begin{array}{l}\text { It is necessary to brush your teeth } \\
\text { in the morning and evening to } \\
\text { maintain their health }\end{array}$ & $88.8 \%$ \\
\hline Q2 & $\begin{array}{l}\text { Using fluoride tooth paste en- } \\
\text { hances the tooth enamel }\end{array}$ & $55.8 \%$ \\
\hline Q3 & $\begin{array}{l}\text { It is necessary to visit the dentist } \\
\text { for control (when painless) at } \\
\text { least 1 time a year }\end{array}$ & $88.3 \%$ \\
\hline Q4 & $\begin{array}{l}\text { It is necessary to clean the teeth } \\
\text { with the dental floss to remove the } \\
\text { residue of food between the teeth } \\
\text { at least once a day }\end{array}$ & $87.1 \%$ \\
\hline Q5 & $\begin{array}{l}\text { It is necessary to inform the pa- } \\
\text { tient that the requested or pre- } \\
\text { scribed drug contains sugars and } \\
\text { that therefore may affect their oral } \\
\text { health }\end{array}$ & $83.8 \%$ \\
\hline
\end{tabular}

\section{Open-ended question}

Table 3. Q6.Categorisation of answers related to List of drugs and the type of changes reported by respondents that can cause unwanted changes in the teeth or mucous membranes in the oral cavity.

\begin{tabular}{|l|l|l|l|}
\hline & & $\begin{array}{l}\text { Total } \\
\text { num- } \\
\text { ber } \\
\text { of an- } \\
\text { Swers } \\
\text { n }\end{array}$ & $\begin{array}{l}\text { \%wer } \\
\text { swer } \\
\text { in Total }\end{array}$ \\
\hline 1 & $\begin{array}{l}\text { iron preparations with or without } \\
\text { listed change }\end{array}$ & 20 & $26.7 \%$ \\
\hline 2 & $\begin{array}{l}\text { tetracycline with or without listed } \\
\text { change }\end{array}$ & 20 & $26.7 \%$ \\
\hline 3 & don't know & 16 & $21.3 \%$ \\
\hline 4 & other & 9 & $12.0 \%$ \\
\hline 5 & $\begin{array}{l}\text { antibiotics with or without listed } \\
\text { change }\end{array}$ & 3 & $4.0 \%$ \\
\hline 6 & don't want to answer & 3 & $4.0 \%$ \\
\hline 7 & fluorides without listed change & 1 & $1.3 \%$ \\
\hline 8 & $\begin{array}{l}\text { gingival hyperplasia without list- } \\
\text { ed drug }\end{array}$ & 1 & $1.3 \%$ \\
\hline 9 & $\begin{array}{l}\text { inhalation drugs without listed } \\
\text { change }\end{array}$ & 1 & $1.3 \%$ \\
\hline 10 & sugar pastilles and caries & 1 & $1.3 \%$ \\
\hline & Grand Total & 75 & $100.0 \%$ \\
\hline
\end{tabular}

Chart 2. List of drugs and type of changes that can cause unwanted changes in the teeth or mucous membranes in the oral cavity categories

Table 4. Q7. Categorisation of answers related to question what kind of mouthwash would you rec- ommend to adult patient for the prevention / treatment of gingivitis?

\begin{tabular}{|l|l|l|}
\hline & $\begin{array}{l}\text { Total num- } \\
\text { ber of an- } \\
\text { swers } \\
\text { categorisation of answers }\end{array}$ & $\begin{array}{l}\text { \% of an- } \\
\text { swers in } \\
\text { Total }\end{array}$ \\
\hline $\begin{array}{l}\text { a commercial name for a } \\
\text { mouthwash intended for the } \\
\text { purpose }\end{array}$ & 32 & $54.2 \%$ \\
\hline don't know & 17 & $28.8 \%$ \\
\hline don't want to answer & 6 & $10.2 \%$ \\
\hline Missing / No Response & 4 & $6.8 \%$ \\
\hline Grand Total & 59 & $100.0 \%$ \\
\hline
\end{tabular}

Table 5. Q8. Categorisation of answers related to question What is the possible fluoride concentration in the toothpaste?

\begin{tabular}{|l|l|l|}
\hline categorisation of answers & $\begin{array}{l}\text { Total num- } \\
\text { ber of an- } \\
\text { swers } \\
\text { n }\end{array}$ & $\begin{array}{l}\text { \% of an- } \\
\text { swers in } \\
\text { Total }\end{array}$ \\
\hline don't know & 42 & $67.7 \%$ \\
\hline Missing / No Response & 10 & $16.1 \%$ \\
\hline don't want to answer & 7 & $11.3 \%$ \\
\hline some answer & 3 & $4.8 \%$ \\
\hline Grand Total & 62 & $100.0 \%$ \\
\hline
\end{tabular}

\section{Attitudes}

Pharmacy interns were asked about their attitudes regarding the role of Pharmacist trough counselling, patient information and education in the maintence and improvement of oral health in the community. $96.8 \%$ of respondents answered strongly agree and agree to this claim.

Some questions assessed participants attitudes regarding their education toward oral health. As for the previous question, answers were based on 5 point Likert scale from strongly agree to strongly disagree.

$72.6 \%$ of the respondents disagree and strongly disagree that they acquired enough knowledge about oral health in their previous education.

93.5\% of the respondents strongly agree and agree that is necessary that they continue to work on improving their oral health knowledge through various forms of education.

Some of the respondents suggestions regarding 
the way and type of education / information for improvement of their knowledge about oral health were: educational meetings, lectures, seminars $(16.4 \%)$, lectures in collaboration with dentists, communication with dentists $(9.8 \%)$, web based self-learning (9.8\%), but actually, $21,3 \%$ of answers were do not know. Since, this was an open-ended question, answers were categorised.

\section{Discussion}

Pharmacy interns during their professional work were actively involved in providing oral health advices.

Our results are in line with results of other study (Al-Saleh et. al., 2017). Toothache was the second most frequent request. More or less, advices requested in our study are consistent with advices regarding oral health conditions or products requested in other studies. $(2,4,8,16)$.

There is difference in most frequent advice requested in our study related to other studies. Most frequent advice requested in our study is Other gum related problems (21.3\%) which is not assessed as advice in other studies. This could be due the type of question in our study, which was open-ended. Data obtained in this way are qualitative in nature and therefore were analysed in mixed manner. Data obtained in other studies were mostly closed-ended. Answers categorised in the category Other gum related problems were gum pain, gum redness, gum tenderness etc. excluded gum bleeding.

Other important issue is that respondents did not reported dental floss as request for advice. Dental floss is important oral hygiene product in everyday practice for the maintenance of interdental spaces hygiene which are almost impossible to brush and clean with ordinary toothbrush. Not requesting such product in the pharmacy may be due to the grocery store purchasing habit. However, advice about Interdental brushes which serve for same purpose was the answer in $1.8 \%$ of cases.

Regarding the knowledge of participants about prevention oriented oral health behaviors, $80.8 \%$ of participants strongly agree and agree to recommended oral health behaviors.
The most frequent answers related to listing of drugs that can cause unwanted changes in the teeth or mucous membranes in the oral cavity, as well as the type of changes were iron preparations with or without listed change, tetracycline with or without listed change (26.7\% each). Twenty one point three percent of answers were do not know. Only $1.3 \%$ of answers were sugar pastilles and caries.

In $54.2 \%$ of cases, the respondents named a commercial name for a mouthwash intended for the purpose of the prevention / treatment of gingivitis for an adult patient.

Regarding the question about the possible fluoride concertation in the toothpaste, the participants answered do not know $67.7 \%$ and do not want to answer $11.3 \%$.

Results explanation is by the fact that younger pharmacists do not have enough experience to develop their personal knowledge and be at ease to provide advices for oral health-related issues, especially in the absence of education/information during their pharmacy curriculum. (4)

Good knowledge about commercial names of mouthwashes may be due to contact with sales representatives who give instructions/advices about oral health products, but it is advisable for pharmacist to know active substance in oral health products intended for therapeutic purposes. Further studies are needed to evaluate this correlation.

One question was related to the assessment of participant attitudes toward their role in the maintenance and improvement of oral health in the community, which was presented in the form of claim. $96.8 \%$ of respondents answered strongly agree and agree to this claim.

In relation to education about oral health topics, $72.6 \%$ of participants disagree and strongly disagree that they acquired enough knowledge about oral health in their previous education.

Moreover, $93.5 \%$ of respondents strongly agree and agree that is necessary that they continue to work on improving your oral health knowledge through various forms of education.

Some of the respondents suggestions regarding the way and type of education / information for 
improvement of their knowledge about oral health were: educational meetings, lectures, seminars (16.4\%), lectures in collaboration with dentists, communication with dentists $(9.8 \%)$, web based self-learning (9.8\%), but actually, $21,3 \%$ of answers were don't know. Since this was an open -ended question, the answers were categorized.

The data in the present study showed the important role and contribution of the pharmacy interns in improving oral health. The pharmacy interns were willing to improve their knowledge through training programs and promotional materials. The pharmacists trained in oral health can advise the public on the most appropriate choices of dental products and the use of fluoride supplements.

Our research is consistent with other study (8) which show that pharmacists generally wish to play a more active role in health promotion.

They are presently an underused resource, and it is only now that they are beginning to get the recognition they deserve. There is a definitive need for training of pharmacists and providing them with access to information on available dental services, oral health care products and oral conditions related to side effect of drugs.

This study shows that pharmacy interns have an important role in oral health and provides evidence supporting the need for growing partnerships/collaborations between pharmacy and dental healthcare professionals and organisations to develop, implement and evaluate evidence-based resources, interventions and services to deliver improved and responsive oral healthcare within communities. (3)

Studies are needed to examine the extent of pharmacist training in oral health. Data gathered from such studies will be invaluable in developing appropriate training standards, model curricula, and clinical best practices. (15)

As described by several published articles $(3,8$, 16 ), almost all pharmacists agreed that the collaboration between dentists and pharmacists could offer more effective oral health promotion strategies, especially that most of them reported knowing a dental clinic in their pharmacy vicinity.

\section{Strengths and limitations of this study}

To the best of our knowledge, this is the first study in FB\&H evaluating the KAP of pharmacy interns who work in community pharmacies toward oral health and dental care.

Even if some scientists have voiced their concern over the applicability of KAP surveys, they remain an interesting tool that offers accurate information about knowledge, attitude and practice that can be used for educational purposes $(4,17)$

The other limitation of this study is that, this study has small sample size and focusing only on pharmacy interns who work under professional supervision in community pharmacies instead of pharmacist.

Also, some question in the questionnaire were open-ended which gave opportunity to gain more data on the issue, but data acquired in such manner are even more difficult to analyse. Therefore, we categorised answers in purpose of quantitative assessment, but comparison of our results with results of other relevant studies was limited so as deeper statistical analysis.

\section{CONCLUSIONS}

In conclusion, this study shows that pharmacy interns in FB\&H have knowledge about preventive oral health behaviours, and oral health care and have positive attitude to their important role in maintenance of oral health despite all barriers and difficulties. The pharmacist interns expressed their need for education/training to enhance their practice. Pharmacy interns in FB\&H are approached for variety of oral health advices including oral health conditions as well as oral hygiene products. Continuing education courses and programs should be tailored according to their needs to maximize their potential of promoting oral health in the community.

Pharmacy undergraduate curricula should be revised and more collaboration with dental schools should be established. In addition, communication and interaction between pharmacists and dentists should be established including emergency referral protocols. These measures would increase pharmacists' knowledge and experience in oral health, and would effectively serve the clients. 


\section{Key points}

Community pharmacists can play an important role in oral health promotion.

Addition of specific oral health subjects in the pharmacy curriculum and/ or continuing education may enable pharmacists to provide better oral health advice.

Collaboration between pharmacists and other healthcare professionals, especially dentists could offer more effective oral health promotion strategies.

\section{REFERENCES}

1. MC Watson, CM Bond, JM Grimshaw, J Mollison, A Ludbrook, AE Walker, Educational strategies to promote evidence-based community pharmacy practice: a cluster randomized controlled trial (RCT), Family Practice, Volume 19, Issue 5, October 2002, Pages 529-536, https:// doi.org/10.1093/fampra/19.5.529

2. Bawazir OA. Knowledge and attitudes of pharmacists regarding oral healthcare and oral hygiene products in riyadh, Saudi Arabia, J Int Oral Health.2014;6(6):10-3.

3. Freeman CR, Abdullah N, Ford PJ, Taing MW. A national survey exploring oral healthcare service provision across Australian community pharmacies. BMJ Open. 2017;28;7(9):e017940. doi: 10.1136/bmjopen-2017-017940.

4. Hajj et al. Assessment of knowledge, attitude and practice among community pharmacists towards dental care: A national cross sectional survey. Saudi Pharmaceutical Journal. 2019; https://doi.org/10.1016/j.jsps.2019.01.010Get rights and content

5. Sturrock et al,. Attitudes and perceptions of GPs and community pharmacists towards their role in the prevention of bisphosphonate-related osteonecrosis of the jaw: a qualitative study in the North East of England, BMJ Open. 2017; 7 (9), p. e016047

6. Goel P, Ross-Degnan D, Berman P, Soumerai S. Retail pharmacies in developing countries: A behavior and intervention framework. Soc Sci Med. 1996;42(8):1155-61.

7. Ghalamkari HH, Saltrese-Taylor A, Ramsden M.). Evaluation of a pilot health promotion project in pharmacies:1 Quantifying the pharmacist's health promotion role. Pharm J.1997;258:138-43.

8. Priya S., Madan Kumar PD, Ramachandran S. Knowledge and attitudes of pharmacists regarding oral health care and oral hygiene products in Chennai city. Indian J Dent Res.2008;19(2):104-8.

9. Anderson C. Health promotion in community pharmacy: The UK situation. Patient Educ Couns. 2000;39:285-91.

10. Chestnutt, I., Taylor, M. \& Mallinson, E. The provision of dental and oral health advice by community pharmacists. Br Dent J 1998; 184, 532534 (. https://doi.org/10.1038/sj.bdj.4809690

11. Rajiah, Kingston, and Chow Jun Ving. An assessment of pharmacy students' knowledge, attitude, and practice toward oral health: An exploratory study. J Int Soc Prev Community Dent. 2014 Nov;4(Suppl 1):S56-62. doi: 10.4103/2231-0762.144601. PMID: 25452930; PMCID: PMC4247553.

12. Freeman R. Barriers to accessing and accepting dental care, Br Dent J., 1999; 187 (2): 81-84

13. Maunder, P., Landes, D. An evaluation of the role played by community pharmacies in oral healthcare situated in a primary care trust in the north of England. Br Dent J 2005; 199: 219-223 https://doi.org/10.1038/sj.bdj.4812614

14. Internet :American Dental Association. Oral Health and Well-Being in the United States, cited 2020 November,17 available from https:// www.ada.org/en/science-research/health-policy-institute/oral-health-and-well-being

15. Cohen, Leonard A.. Enhancing pharmacists' role as oral health advisors. J Am Pharm Assoc 2003;53(3):316-21. doi: 10.1331/JAPhA.2013.12017

16. Al-Saleh et. Al.. Role of community pharmacists in providing oral health advice in the Eastern province of Saudi Arabia. Saudi Dent J.,2017; 29(3): 123-128. doi: 10.1016/j.sdentj.2017.03.004

17. Launiala, Annika.How much can a KAP survey tell us about people's knowledge, attitudes and practices? Some observations from medical anthropology research on malaria in pregnancy in Malawi Anthropology Matters Journal 2009 


\title{
DIPLOMIRANI FARMACEUTI U PROMOCIJI ORALNOG ZDRAVLJA U FEDERACIJI BOSNE I HERCEGOVINE
}

\author{
Milka Dančević-Gojković \& Elma Sokić-Begović ${ }^{2}$ \\ ${ }^{1}$ Public Health Institute of Federation Bosnia and Herzegovina \\ ${ }^{2}$ Federal Ministry of Health
}

\section{SAŽETAK}

Uvod: Farmaceuti u zajednice su zdravstveni djelatnici koji igraju ključnu ulogu u pružanju kvalitetne zdravstvene zaštite ljudima, uključujući probleme vezane uz oralno zdravlje i proizvode za zubnu higijenu, kao dio promocije zdravlja. U cilju boljeg razumijevanja ovih pitanja u $\mathrm{FBiH}$, ovo istraživanje imalo je za cilj procjenu znanja, stavova i prakse magistara farmacije na radu u apotekama u pogledu oralnog zdravlja i obrazovnih potreba farmaceuta, s krajnjim ciljem jačanja njihove uloge u promicanju oralnog zdravlja i prakse oralne higijene.

Metode: Ovo presječno istraživanje provedeno je među pripravnicima ljekarni tokom 2019.godine samopopunjavanjem polustrukturiranog upitnika, kreiranog u sklopu predavanja iz oblasti javnog zdravstva. Rezultati su statistički analizirani pomoću deskriptivne statistike.

Rezultati: Najčešće prijavljena pitanja u vezi sa dentalnim zdravljem farmaceutima tokom prakse u apotekama bili su: (drugi) problemi povezani s oboljenjima desni, kao što su bol, crvenilo, osjetljivost, upala itd., problemi s zuboboljom i protezama, te zahtjevi za solucijama za ispiranje usta, četkice i paste za zube. Što se tiče znanja o prevenciji usmjerenog ka oralnom zdravlju, $80,8 \%$ sudionik se slaže, i u potpunosti slaže s preporučenim zdravstvenim ponašanjem. Sudionici su pokazali pozitivan stav prema svojoj ulozi u oralnoj zdravstvenoj zaštiti oralnog zdravlja uz spremnost da poboljšaju svoje znanje o ovom pitanju.

Zaključak: Studija pokazuje da pripravnici, magistri farmacije, u FBiH imaju dobro znanje o preventivnom ponašanju o oralnom zdravlju, prosječno znanju vezano uz oralnu zdravstvenu zaštitu i imaju pozitivan stav prema svojoj važnoj ulozi u održavanju oralnog zdravlja unatoč svim preprekama i poteškoćama. Farmaceuti su izrazili potrebu za dodatnim obrazovanjem kako bi unaprijedili svoju praksu.

Ključne riječi: farmaceut, oralno zdravlje, promocija, FBiH

Osoba za korespondenciju

Prim dr Milka Dančević-Gojković 1

Zavod za javno zdravstvo Federacije Bosne i Hercegovine

Titova 9,

Sarajevo

Bosna i Hercegovina

e-mail: m.dancevic@zzjzfbih.ba 